\title{
Effects of Chilling on the Length and Number of Epidermal Cells in Petioles of Strawberry Plants during the Rest Period
}

\author{
Takashi Nishizawa and Yuichiro Yasukawa* \\ Faculty of Agriculture, University of Tokyo, Bunkyo-ku, Tokyo 113
}

\begin{abstract}
Summary
On 1 November, 1989, resting strawberry plants of 'Nyoho', 'Hokowase', and 'Morioka 16' (low, medium, and high chill-requiring cultivars for the breaking of the resting state, respectively) were kept at $4^{\circ} / 3^{\circ} \mathrm{C}$ (day/night), under a 12 -hr photoperiod for 0,18 , and 37 days (chilling treatment), and then transferred to a growth chamber maintained at $24^{\circ} / 20^{\circ} \mathrm{C}$ (day/night) under a 12 -hr photoperiod (forcing treatment).

When 'Nyoho' strawberry plants received no chilling (unchilled control treatment), final petiole length and leaf area increased at higher leaf positions than did those of lower leaf position. However, such an increase was not distinct in the other 2 cultivars.

When the plants were chilled, the petiole length, the mean epidermal cell length of a petiole (petiolar cell length), and the leaf area of plants increased significantly, reaching maximum between the 3rd to 6th leaf which emerged during the subsequent forcing period, and then decreased at higher leaf positions. However, the number of epidermal cells per petiole length (number of petiolar cells) increased at higher leaf positions, irrespective of cultivars and duration of chilling.

Petioles of chilled plants were longer than those of unchilled plants, irrespective of leaf positions, because the former had longer cells than those of the latter. The contribution in petiole length by cell division was greater at higher than at lower leaf positions.

Leaves which differentiated after the plants were chilled had petioles which were longer than those at the same position on unchilled plants.
\end{abstract}

\section{Introduction}

Most strawberry cultivars grown in Japan enter the rest in autumn in response to the shortphotoperiod and low-temperature conditions (Darrow and Waldo, 1933; Durner and Poling, 1988; Kimura and Fujimoto, 1971; Kimura et al., 1968). The vegetative growth of the resting strawberry plants is greatly inhibited even if the plants are grown under suitable climatic conditions (Darrow, 1936, 1937; Lee et al., 1970; Otto, 1966; Seyama and Takai, 1986; Fujime and Yamasaki, 1988). To break the resting state, plants are required to receive a certain amount of cumulative low tem-

Received for publication 11 April 1991. A part of this study was presented at the autumn meetings of the Japanese Society for Horticultural Science, Nagano, 1990.

*Present adress: Showa Denko Inc., 3-2 Chidori, Kawasaki, Kanagawa. peratures near freezing (chilling) during the winter (Bailey and Rossi, 1964; Guttridge, 1958; Takai and Seyama, 1966). There are also large differences in the chilling requirement among cultivars (Lee et al., 1968; Takai, 1970). 'Nyoho' requires short chilling (Akagi et al., 1985), whereas 'Hokowase' and 'Morioka 16' require longer chilling (Kimura and Fujimoto, 1971; Seyama and Takai, 1986).

If plants are grown under the long-photoperiod and high-temperatures, the petiole length of the resting strawberry plants does not elongate as much as those of fully chilled plants (Durner and Poling, 1988; Guttridge, 1958; Lee et al., 1968, 1970). Therefore, these researchers have used petiole length as a measure for assessing the chilling requirements in strawberry cultivars. In a previous study, Nishizawa (1990) found that the elongation of petioles of the resting strawberry plants in response to the chilling treatment was largely influenced by the developmental stage in the apical 
crown just prior to the treatment. However, it is not clear if the chilling treatment preconditions the petioles which differentiate after the treatment to elongate during the subsequent long-photoperiod and high-temperature conditions.

The petiole length is regarded as a function of cell length and number per petiole length (Gosselink and Smith, 1967; Guttridge and Thompson, 1959, 1963). Therefore, cell division and/or enlargement seems to be inhibited during the resting period, and conversely, promoted by the chilling treatment. During the vegetative stage, petiole length increases at higher leaf positions under the long-photoperiod and high-temperature conditions because cell division continues (Nishizawa, 1990). However, it is not clear how the length and number of petiolar cells of the resting strawberry plants change in response to the chilling treatment and if there is variation among cultivars.

In the present study, 3 cultivars of strawberry plants with different chilling requirements were chilled from 1 November, then grown under a moderate temperature. The objectives of this study were to: 1) investigate the effects of chilling on the length and number of petiolar cells of successive leaves to expand during the subsequent moderate temprature; and 2) assess the influence of different durations of chilling on varietal responses.

\section{Materials and Methods}

Three strawberry cultivars: 'Nyoho', 'Hokowase', and 'Morioka 16', representing those which require low, medium, and high chilling requirements, respectively, for overcoming their rest (Akagi et al., 1985; Kimura and Fujimoto, 1971; Seyama and Takai, 1986) were used. 'Nyoho' plants were grown in a plastic film greenhouse at the University Research Field. 'Hokowase' and 'Morioka 16' were obtained from the National Research Institute of Vegetables, Ornamental Plants and Tea, Morioka branch. On 20 September 1989, daughter plants were transplanted to plastic pots $(12 \mathrm{~cm}$ diameter) containing a mixture of soil, vermiculite, peat, and leaf mold ( $7: 1: 1: 1$ by volume). The plants were grown in a plastic film greenhouse maintained above $10^{\circ} \mathrm{C}$ and under a naturalphotoperiod. The plants were fed liquid fertilizer (250 ppm N: 100 ppm P: $350 \mathrm{ppm} \mathrm{K}$ ) at the time of irrigation. On 1 November, 10 plants, each with emerging leaves were kept at $4^{\circ} / 3^{\circ} \mathrm{C}$ (day/night) under a 12 -hr photoperiod for 0,18 , and 37 days (chilling treatment); 5 plants per cultivar were transferred to a growth chamber maintained at $24^{\circ} / 20^{\circ} \mathrm{C}$ (day/night) under a 12 -hr photoperiod (forcing treatment). Light in the growth chambers was provided by $40 \mathrm{~W}$ fluorescent lamps and 10 $\mathrm{W}$ incandescent lamps (297 and $5 \mu \mathrm{mol} \cdot \mathrm{m}^{-2} \cdot \mathrm{sec}^{-1}$ photosynthetically active radiations on the surface of leaves, respectively) which were on from 5:00 to 17:00 hr. There was no apparent elongation of the emerging leaf during the chilling treatment. Therefore, this leaf was designated as E-0, and successively emerging leaves during the forcing conditions were consecutively numbered as E- $1, \mathrm{E}-2$, E-3, etc. The plants were restricted to a single bud in the axil of the last leaf below the terminal flower bud. Flowers and runners were removed when they emerged. The eight leaves from E-0 to E-7 were harvested when E-11 leaf emerged, and the petiole length measured. The petioles were cut into 3 equal longitudinal sections along the length of the petiole. The epidermal tissue of 0.5 to $1.0 \mathrm{~cm}$ in length was stripped off from the central portion on the abaxial side of each section, fixed in a FAA solution (formaldehyde : acetic acid : $50 \%$ ethanol; $5: 5: 90, \mathrm{v} / \mathrm{v} / \mathrm{v})$ and stained with $1 \%$ ruthenium red. Fifteen cell lengths of the central portion of each epidermis were measured with a calibrated ocular micrometer. When end walls of a cell were sloping, the length was taken to the mid-point of the sloping (Guttridge and Thompson, 1963). The number of epidermal cells per petiole length (number of petiolar cells) was calculated by dividing the petiole length by the mean length of epidermal cells of a petiole (petiolar cell length).

\section{Results}

On 20 Semptember, the mean petiole length of the uppermost 3 leaves which expanded in the plastic film greenhouse was $20.0 \mathrm{~cm}$ in 'Nyoho', $13.8 \mathrm{~cm}$ in 'Hokowase', and $12.0 \mathrm{~cm}$ in 'Morioka 16 '. However, the petioles measured on 1 November were much shorter than those measured on 20 September (Table 1). The number of leaf initials in the apical crown was 6 (leaves from $\mathrm{E}-0$ to $\mathrm{E}-5$ ) in 'Nyoho' and 7 (leaves from E-0 to E-6) in both 'Hokowase' and 'Morioka 16' at the beginning of the chilling treatment (Table 2). The runners were produced only in 'Nyoho' when it was chilled (Table 3). 
Table 1. The mean petiole length $(\mathrm{cm})$ of the uppermost 3 expanded leaves on 20 Sept. and 1 Nov.

\begin{tabular}{lccc}
\hline Date & 'Nyoho' & 'Hokowase' & 'Morioka 16' \\
\hline 20 Sept. & $20.0 \pm 0.9^{z}$ & $13.8 \pm 0.7$ & $12.0 \pm 0.5$ \\
1 Nov. & $8.3 \pm 0.5$ & $8.6 \pm 0.4$ & $8.5 \pm 0.3$ \\
\hline
\end{tabular}

$z$ Values are the mean \pm S.E.

Table 2. Number of the leaf initials in the apical crown as influenced by duration of chilling treatment. ${ }^{2}$

\begin{tabular}{cccc}
\hline \hline Chilling' (days) $^{\prime}$ & 'Nyoho' & 'Hokowase' & 'Morioka 16' \\
\hline 0 & 5.6 & 6.6 & 7.0 \\
18 & 5.8 & 6.6 & 7.0 \\
37 & 5.8 & 6.8 & 7.2 \\
Significance & NS $^{\mathrm{x}}$ & $\mathrm{NS}$ & $\mathrm{NS}$ \\
\hline
\end{tabular}

${ }^{z}$ The number was counted when the chilling treatment was completed.

${ }^{y}$ Plants were kept at $4 \% 3^{\circ} \mathrm{C}$ (day/night) under a 12 -hr photoperiod from 1 Nov. on.

$x$ NS means non-significant difference based on Duncan's multiple range test, $5 \%$ level.

Table 3. Number of runners formed during the forcing treatment as influenced by duration of chilling treatment. ${ }^{z}$

\begin{tabular}{cccc}
\hline \hline Chilling' (days) & 'Nyoho' & 'Hokowase' & 'Morioka 16' \\
\hline 0 & 0 & 0 & 0 \\
18 & $0.2 \pm 0.1^{\mathrm{x}}$ & 0 & 0 \\
37 & $3.4 \pm 0.4$ & 0 & 0 \\
\hline
\end{tabular}

2 Cumulative number obtained during the forcing treatment until the emergence of the leaf E-11.

${ }^{y}$ Plants were kept at $4^{\circ} / 3^{\circ} \mathrm{C}$ (day/night) under a 12 -hr photoperiod from 1 Nov. on.

${ }^{x}$ Values are the mean \pm S.E.

The petiole length, the petiolar cell length, the number of petiolar cells, and the leaf area of the unchilled plants in 'Nyoho' increased slightly at higher leaf positions. However, no such clear-cut differences among leaves at different position were noted in the other two cultivars.

The chilling treatment preconditioned the leaves to increase in length and area during the subsequent forcing conditions. Plants chilled for 37 days produced leaves with longer petiole and larger area than did those chilled for 18 days, irrespective of leaf positions and cultivars. Petiole length, the petiolar cell length, and the number of petiolar cells reached maximum values between leaves E-3 to E-6, and then decreased at higher leaf positions, irrespective of cultivars and duration of chilling. However, the number of petiolar cells did not decrease when the plants were chilled for 37 days (Fig. 1).

The effects of chilling on the petiole length, the petiolar cell length, and the number of petiolar cells of the chilled plants are shown in Fig. 2 as relative values to those of the plants transferred to the forcing conditions without chilling. The relative petiole length attained maximum in leaf $\mathrm{E}-2$ or $\mathrm{E}-3$ and then decreased markedly at higher leaf positions, irrespective of cultivars and duration of chilling. The increase in the petiole length at the peak value was due mainly to the longer petiolar cell length, and not to the increase in the number of petiolar cells. On the other hand, at higher leaf positions, the number of petiolar cells increased gradually with a concurrent decrease in petiolar cell length and petiole length. The contribution by the increased number of petiolar cells, in some cases, exceeded that of petiolar cell length, especially by leaves E- 5 to E-7.

\section{Discussion}

The petiole length of the uppermost 3 unfolded leaves in November was shorter than that in September (Table 1). When the plants were not chilled, the petiole length of the leaves to emerge during the subsequent forcing conditions also remained short, and no runner was formed (Fig. 1 and Table 3 ). This indicates that the rest period of these plants was not broken completely (Durner and Poling, 1988).

Takai (1970) reported that the upper limit of the effective chilling temperature for the breaking of the resting state in strawberry plants was about $10^{\circ} \mathrm{C}$. In our experiment, the air temperature in the plastic film greenhouse was maintained well above $10^{\circ} \mathrm{C}$. Therefore, the plants did not perceive any effective chilling before the chilling treatment was begun.

Gosselink and Smith (1967) indicated that the elongation of petioles in strawberry plants continued approximately 2 weeks after leaf emergence. In our experiment, the leaf emergence interval (days per leaf) was 6 to 8 (data were not shown) and the leaves from E-0 to E-7 were harvested when the leaf $\mathrm{E}-11$ emerged. Therefore, it 

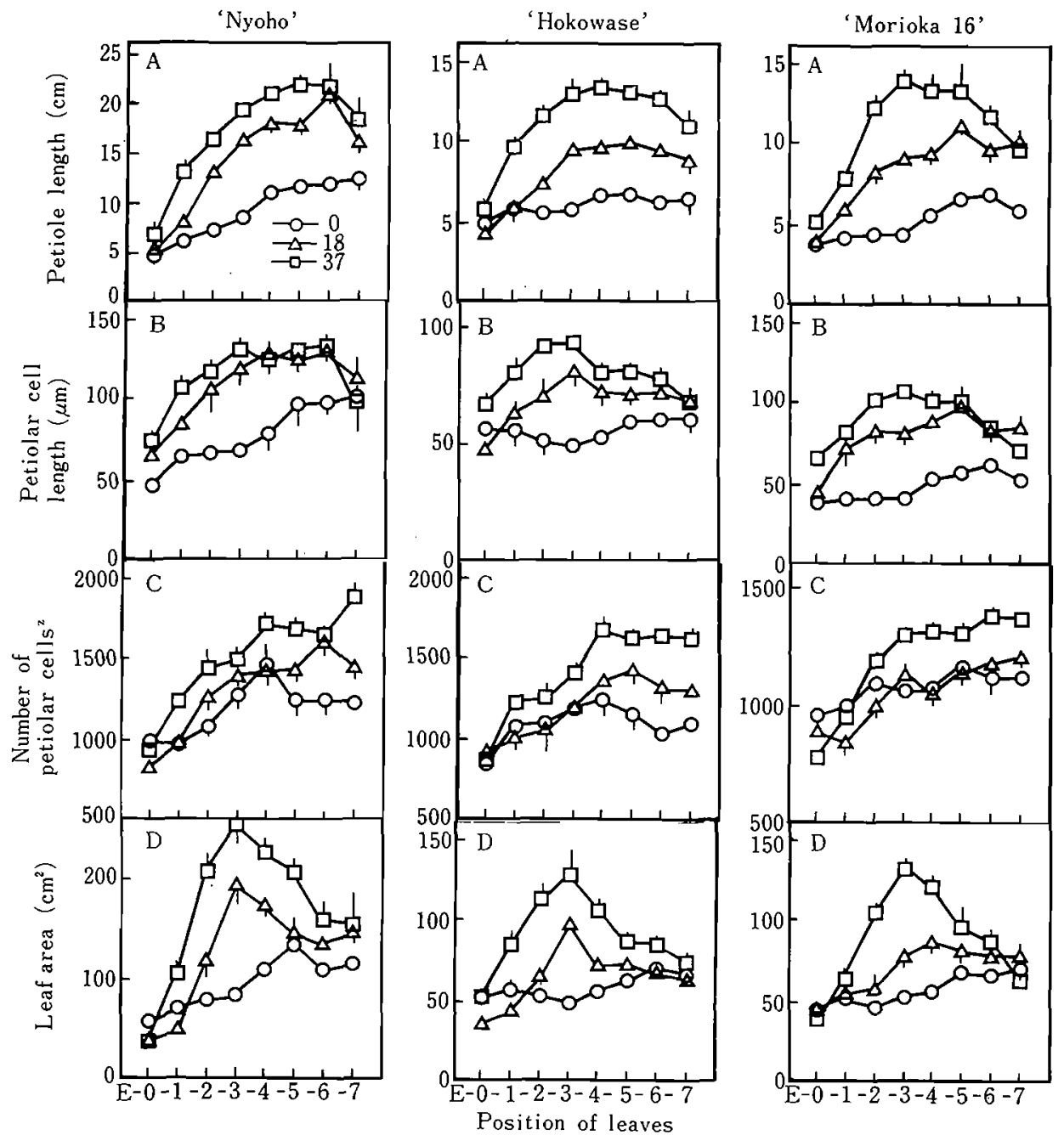

Fig. 1. The effect of chilling on the petiole length (A), the petiolar cell length (B), the number of petiolar cells (C), and the leaf area (D). The plants were kept at $4^{\circ} / 3^{\circ} \mathrm{C}$ (day/night) under a 12 -hr photoperiod for 0,18 , and 37 days from 1 Nov., then forced at $24^{\circ} / 20^{\circ} \mathrm{C}$ under a 12 -hr photoperiod. The emergent leaf at the beginning of the chilling treatment was designated as $\mathrm{E}-0$ and the subsequent younger leaves were numbered as E-1, E-2, E-3, etc. Vertical bars represent S.E.

${ }^{z}$ Values are the petiole length divided by the petiolar cell length.

is clear that the petioles of the leaves from E-0 to E-7 had attained their final length at harvest.

The petiole length of chilled plants became longer than that of the unchilled plants, irrespective of cultivars. The chilling treatment for 37 days was more effective for the breaking of the resting state than that for 18 days (Fig. 1).

Petiole length, the petiolar cell length, and the number of petiolar cells of the chilled plants relative to those of the unchilled plants indicate that the increase in the petiole length of 4 leaves from leaves E-0 to E-3 was mainly attributed to the increase in the petiolar cell length. The contribution by the number of petiolar cells increased gradually from leaves E-3 to E-7, with a concurrent decrease by the contribution of petiolar cell length, irrespective of cultivars and duration of chilling treatment (Fig. 2). Guttridge and Thompson (1963) indicated that the active cell division phase of strawberry petioles ceased at near emergence of the leaves and that the rapid elongation after emergence was attributed to the increase in the 


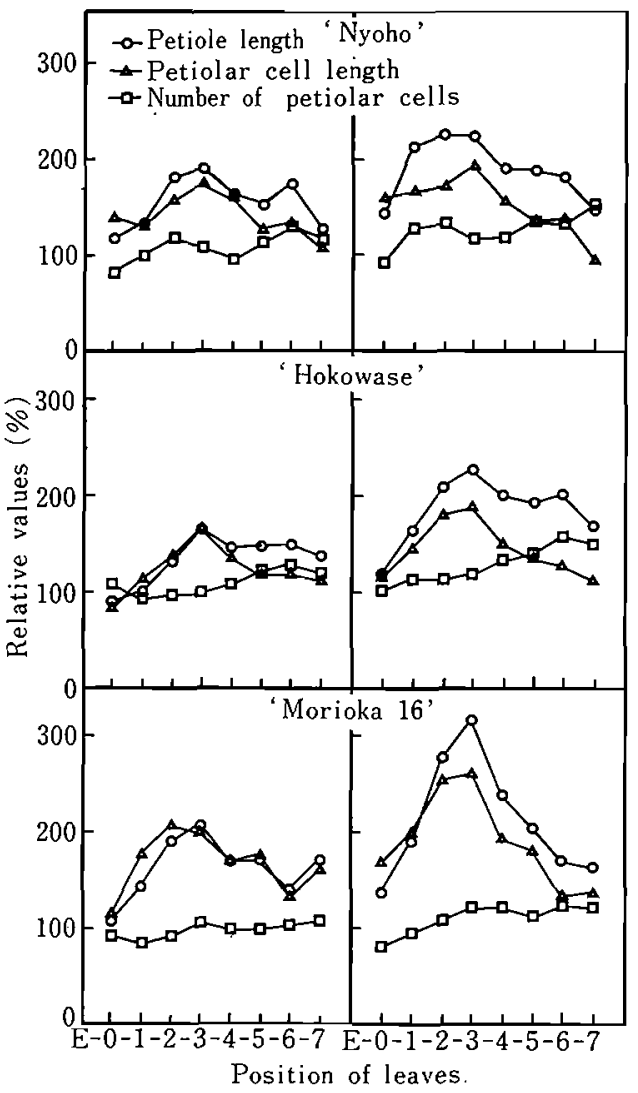

Fig. 2. The petiole length, the petiolar cell length, and the number of petiolar cells of the chilled plants relative to those of the unchilled plants. The plants were chilled for 18 days (left) or 37 days (right) from 1 Nov. See Fig. 1 for the details.

petiolar cell length. The differential effects of the chilling treatment on the petiolar cell length and number of petiolar cells might be attributed to the difference in developmental stages of the leaf initials in the apical crown. The chilling treatment was probably initiated too late to promote cell division in leaf primordia as leaves approached emergence.

Guttridge and Thompson $(1959,1963)$ indicated that both the petiolar cell length and number of petiolar cells in strawberry plants increased by $\mathrm{GA}_{3}$ application. Avigdori-Avidov et al. (1977) indicated that the level of gibberellin-like substances in the resting strawberry plants increased markedly after the chilling treatment. These results suggest that gibberellins produced after the chilling treatment promoted the increase in the petiolar cell length and/or the number of petiolar cells.

In some deciduous trees, the chilling treatment on the resting period preconditions shoots to mobilize stored reserves from roots during the subsequent high-temperature condition (Arnold and Young, 1990; Young and Werner, 1984). In our experiment, the chilling treatment preconditioned the petiolar cells to increase in number at higher leaf positions, resulting in petiole to attain maximum length in leaves E-3 to E-6; petiole length decreased at higher leaf positions (Fig. 1). The probable cause for the decrease in the petiole length at higher leaf positions is attributed to the depletion of stored reserves.

The petiole length of the leaf E-7 of the chilled plants was significantly longer than that of the unchilled plants (Fig. 1). Table 2 shows that the leaf E-7 differentiated under the forcing conditions, irrespective of cultivars. Therefore, it is clear that the chilling treatment preconditions the petioles of leaves which are differentiated not only before, but also after the chilling treatment to increase in length; though the enhancement attains its peak in leaves E-3 to E- 6 and then becomes smaller at higher leaf positions (Figs. 1 and 2).

Changes in the leaf area influenced by the chilling treatment were similar to those in the petiole length. Therefore, the fundamental bases why chilling affects cell size and number of leaf lamina might be similar to those which influence the petioles.

\section{Acknowledgement}

The authors wish to thank Prof. R. Sakiyama of the University of Tokyo and Dr. Y. Shishido of Morioka branch, National Research Institute of Vegetables, Ornamental Plants and Tea for their helpful comments. We are also grateful to Dr. $\mathrm{H}$. Miura of Kurume branch, National Research Institute of Vegetables, Ornamental Plants and Tea, Mr. T. Nosaka and Mr. M. Hukuda of Kaneko Nursery and Bulb Inc. for generously supplying samples.

\section{Literature Cited}

Akagi, H., T. Ohwada, H. Kawasato, K. Nojiri, T. Yasukawa, O. Cho and A. Katoh. 1985. Nyoho, a new strawberry cultivar. Bull. Tochigi Agr. Exp. Stn. 31:29-41. (In Japanese with English summary).

Arnold, M. A. and E. Young. 1990. Growth and protain 
content of apple in response to root and shoot temperature following chilling. HortScience $25: 1583-1588$.

Avigdori-Avidov, H., E. E. Goldschmidt and N. Kendar. 1977. Involvement of endogenous gibberellins in the chilling requirements of strawberry (Fragaria $\times$ ananassa Duch.). Ann. Bot. 41 : 927-936.

Bailey, J. S. and A. W. Rossi. 1964. Responses of Catskill strawberry plants to digging date and storage period. Proc. Amer. Soc. Hort. Sci. 84 : 310-318.

Darrow, G. M. 1936. Response of strawberry varieties and species to duration of the daily light period. U.S.D.A. Tech. Bull. $453: 1-31$.

Darrow, G. M. 1937. Breaking the rest period of the strawberry by long days at high temperatures. Science $85: 391-392$.

Darrow, G. M. and G. F. Waldo. 1933. Photoperiodism as a cause of the rest period in strawberries. Science $77: 353-354$.

Durner, E. F. and E. B. Poling. 1988. Strawberry developmental responses to photoperiod and temperature. A review. Adv. Strawberry Prod. 7:6-15.

Fujime, Y. and N. Yamasaki. 1988. Effects of pretreatment, day length and temperature on induction and breaking of dormancy in strawberry plants. J. Japan Soc. Hort. Sci. 56 : 444-451. (In Japanese with English summary).

Gosselink, J. G. and C. R. Smith. 1967. Vegetative growth responses of strawberry plants to differing photoperiods. Hort. Res. $7: 24-33$.

Guttridge, C. G. 1958. The effects of winter chilling on the subsequent growth and development of the cultivated strawberry plant. J. Hort. Sci. $33: 119-127$.

Guttridge, C. G. and P. A. Thompson. 1959. Effect of gibberellic acid on length and number of epidermal cells in petioles of strawberry. Nature $183: 197-198$.

Guttridge, C. G. and P. A. Thompson. 1963. The effect of daylength and gibberellic acid on cell length and number in strawberry petioles. Physiol. Plant. $16: 604-614$.

Kimura, M. and K. Fujimoto. 1971. Studies on the dormancy of strawberries. 2. The influence of daylength and temperature on the entrance of the dormancy. Bull. Nara Agr. Sta. 3:29-36. (In Japanese with English summary).
Kimura, M., T. Hisatomi and K. Fujimoto. 1968. Studies on the dormancy of strawberries. 1. The influence of daylength and $\mathrm{CCC}(2$-chloroethyl trimethylammonium chloride) on the entrance of the dormancy. Bull. Nara Agr. Sta. 2:17-28. (In Japanese with English summary).

Lee, B. Y., K. Takahashi and T. Sugiyama. 1968. Studies on dormancy in strawberry plants. I. Varietal differences in chilling requirement to break dormancy. J. Japan Soc. Hort. Sci. 37 : 129-134. (In Japanese with English summary).

Lee, B. Y., K. Takahashi and T. Sugiyama. 1970. Studies on dormancy in strawberry plants. II.Vegetative and flowering response of Donner variety transfered from the open to a greenhouse at different dates in autumn and winter. J. Japan Soc. Hort. Sci. 39:26-32. (In Japanese with English summary).

Nishizawa, T. 1990. Effects of daylength on cell length and cell number in strawberry petioles. J. Japan Soc. Hort. Sci. 59 : 533-538. (In Japanese with English summary).

Otto, L. J. and M. N. Dana. 1966. Dormancy and growth of the strawberry plant. J. Amer. Soc. Hort. Sci. $89: 322-330$.

Seyama, N. and T. Takai. 1986. Study on the seasonal pattern of the growth and flower formation of strawberry plants as related to environment and endogenous physiological conditions. Bull. Hort. Res. Stn. B6:31-77. (In Japanese with English summary).

Takai, T. 1970. Effective temperature for chilling and interaction of chilling and photoperiod on growth response of strawberry varieties. Bull. Hort. Res. Stn. C6:91-101. (In Japanese with English summary).

Takai, T. and N. Seyama. 1966. The growth response of strawbery varieties to chilling. Bull. Hort. Res. Stn. C4:73-86. (In Japanese with English summary).

Young, E. and D. J. Werner. 1984. Effects of rootstock and scion chilling during rest on resumption of growth in apple and peach. J. Amer. Soc. Hort. Sci. $109: 548-551$. 
休眠期のイチゴの株に与えた低温処理が葉柄の表皮細胞長と表皮細胞数に及ぼす影響

西沢 隆・安川雄一郎

東京大学農学部 113 東京都文京区弥生

摘 要

休眠期のイチゴ女峰”，“宝交早生”抢よび ‘盛岡16号” (休眠打破に必要な低温要求量がそれぞれ，少ない，中 間および多い）の3品種を供試した。1989年11月1日 に $4 \% / 3{ }^{\circ} \mathrm{C}$ (昼/液)・12時間日長下で $0 ， 18 な い し 37$ 日間低温処理した後, $24^{\circ} / 20^{\circ} \mathrm{C}$ (昼/夜) 12 時間日長 に移した(高温処理).

1. 低温処理しない場合 (対照区), “女峰”は高温処 理下で展開する葉の葉柄長と葉面積が上位葉ほど増加 する傾向を示した。しかし，他の 2 品種では“女峰ほほど 顕著に增加しなかった.

2. 低温処理した株では, 葉柄長, 葉柄の平均表皮 細胞長 (葉柄の細胞長) および葉面䅡が，その後の高 温処理下で上位葉はど堌加した。これらの値は高温処
理開始後 3 番目 (E-3) から 6 番目 $(\mathrm{E}-6)$ にかけて 出葉する葉で最大值を示し，それより上位葉では減少 した.しかし，葉柄長当たりの表皮細胞数（葉柄の細 胞数）は，供試した品種や低温処理期間によらず上位 葉ほど增加した。

3. 低温処理した株では，対照区の株と比べて，ど の葉位でも葉柄長が長くなった。これは, 前者では後 者にくらべ主に細胞長が増加したことによるものであっ た。しかし，上位葉では葉柄長の增大に対する細胞数 増加の寄与率が高くなった。

4. 低温処理により，低温処理を開始した時点で分 化していた葉の葉柄だけでなく，高温処理開始後に分 化する葉の葉柄長も对照区より增加した。 